\title{
Model of incentive system for employees: A case of a manufacturing company in Croatia
}

\begin{tabular}{|c|c|}
\hline \multicolumn{2}{|c|}{$\begin{array}{l}\text { Authors: } \\
\text { Maria Jakovljevic }{ }^{1} \text { (D) } \\
\text { Jelena Zupan }{ }^{2} \text { (D) } \\
\text { Alfred Coleman }\end{array}$} \\
\hline \multicolumn{2}{|c|}{$\begin{array}{l}\text { Affiliations: } \\
{ }^{1} \text { School of Computing, } \\
\text { College of Science, } \\
\text { Engineering and Technology, } \\
\text { University of South Africa, } \\
\text { South Africa }\end{array}$} \\
\hline \multicolumn{2}{|c|}{$\begin{array}{l}{ }^{2} \text { Department of Financial } \\
\text { Services, Open University } \\
\text { Zadar, Croatia }\end{array}$} \\
\hline \multicolumn{2}{|c|}{$\begin{array}{l}{ }^{3} \text { School of Computing, } \\
\text { College of Science, } \\
\text { Engineering and Technology, } \\
\text { University of South Africa, } \\
\text { South Africa }\end{array}$} \\
\hline \multicolumn{2}{|c|}{$\begin{array}{l}\text { Corresponding author: } \\
\text { Maria Jakovljevic, } \\
\text { jakovm@unisa.ac.za }\end{array}$} \\
\hline \multicolumn{2}{|c|}{$\begin{array}{l}\text { Dates: } \\
\text { Received: } 01 \text { June } 2016 \\
\text { Accepted: } 28 \text { Jan. } 2018 \\
\text { Published: } 27 \text { Sept. } 2018\end{array}$} \\
\hline \multicolumn{2}{|c|}{$\begin{array}{l}\text { How to cite this article: } \\
\text { Jakovljevic, M., Zupan, J. \& } \\
\text { Coleman, A., 2018, 'Model of } \\
\text { incentive system for } \\
\text { employees: A case of a } \\
\text { manufacturing company in } \\
\text { Croatia', South African } \\
\text { Journal of Business } \\
\text { Management 49(1), a191. } \\
\text { https://doi.org/10.4102/ } \\
\text { sajbm.v49i1.191 }\end{array}$} \\
\hline \multicolumn{2}{|c|}{$\begin{array}{l}\text { Copyright: } \\
\text { (C) 2018. The Authors. } \\
\text { Licensee: AOSIS. This } \\
\text { is licensed under the } \\
\text { Creative Commons } \\
\text { Attribution License. }\end{array}$} \\
\hline \multicolumn{2}{|l|}{ Read online: } \\
\hline 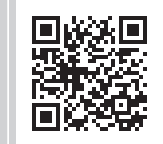 & $\begin{array}{l}\text { Scan this QR } \\
\text { code with your } \\
\text { smart phone or } \\
\text { mobile device } \\
\text { to read online. }\end{array}$ \\
\hline
\end{tabular}

Background: One of the main determinants of a company's business performance is the complete mobility and orientation of its employees towards realising the goals of the company. No single aspect of the company has such a powerful, and simultaneously, invisible influence on the behaviour and feelings of its employees as the organisational climate. Organisational learning creates a climate that encourages employees to learn and to develop their potential.

Objectives: The aim of this study is to investigate the incentives and the factors of an organisational climate required to develop a model of an incentive system to motivate employees to work better.

Method: A quantitative research methodology was used and data was collected by using a closed-ended type of questionnaire. Data was analysed using descriptive and inferential statistics.

Results: The results show that the employees would prefer more incentives, and the factors of a positive organisational climate were far lower than expected by its employees and even lower than what they considered to be essential in order to perform their jobs effectively and to contribute to achieving company objectives.

Conclusion: Incentive systems are crucial to employees and the organisational climate and employee satisfaction should be constantly monitored and empowered through an integrated model of incentive system.

\section{Introduction}

To a large extent, the debate on the importance of monetary incentives and other, non-monetary tools of management in motivating workers continues (Dur, Non \& Roelfsema 2010). Monetary incentives are often not considered the most important motivator, neither by workers nor managers (Dur et al. 2010). Many workers consider task enjoyment and moral concerns to be stronger motivators than monetary incentives (Dur et al. 2010). For the development of a learning organisation, it is necessary to develop and establish the appropriate climate as an integral part of the organisational culture (Kurtić 2009). Insufficient research has been conducted on the influence of incentives and the factors of organisational climate on the productivity of employees in Croatia. The consequence of this is that there is a lack of knowledge about the effect of incentives and corporate climate on the motivation of employees.

Based on this problem, a case study was conducted to identify the incentives and factors of organisational climate and to examine their relevance and importance to employees with a company in Croatia. The purpose of this research is to illuminate the fact that employee incentive systems are of fundamental importance to the development of skills, leading to better performance. A manufacturing company in Croatia proved to be an example of this. The emphasis is on the organisational climate factors such as awareness, the freedom to express opinions, a relationship of trust and creative thinking that affect productivity, efficiency and the motivation of employees. The aim of this study is to determine which incentives are important to employees, whether different incentive systems are sufficiently present or not and whether currently present organisational climate factors promote organisational learning.

This study was conducted in two phases. The objective of the first phase was to create a conceptual model based on current research. This conceptual model introduces the second phase, which 
consists of empirical research of employees' incentives. The objective of the second phase was to create an integrated model of incentive systems (MIS).

\section{Phase I}

Based on the problem, the purpose and the objectives of the research, the following research questions (RQs) were formulated:

- RQ1: Which incentives are used to stimulate employees to increase their performance?

- RQ2: How do employee benefits affect the organisation's ability to attract, retain and motivate employees?

- RQ3: How do organisational climate factors influence the sense of satisfaction and productivity among employees?

\section{Phase II}

To provide further elaboration and answers to the research questions the following four null hypotheses were compiled:

- Hypothesis 1: Financial incentives are more important than non-financial incentives at the middle and lower management levels.

- Hypothesis 2: There is no difference between the level of presence and the importance of financial incentives at the middle and lower management levels.

- Hypothesis 3: There is no difference between the level of presence and the importance of non-financial incentives at the middle and lower management levels.

- Hypothesis 4: There is no difference between the importance of organisational climate factors and their presence at the middle and lower management levels.

The theoretical framework of the incentive system, its processes and designs, factors, objectives and strategies are explained in the next section.

\section{The framework of incentive systems for employees in an organisation}

\section{Incentive systems for employees}

Organisations have to utilise mechanisms to facilitate assignments and the jobs for which employees are most suitable (Schottner 2010). Unstable business trends have made the labour force the most vital asset and satisfied employees are in demand (Ahmed et al. 2011). If workers feel they are being treated fairly and with respect, these attitudes will develop further and positively influence their behaviour (Kamery 2004).

Organisations often offer employees an informal understanding of promotions, salary increases, job security and so on. All these can potentially have a significant influence on a firm's productivity as they require employees to trust that their productive efforts will be fairly rewarded in the future (Hales \& Williamson 2009). Organisational commitment can be achieved through organisational trust and motivation. When employees trust the organisation they work for, they believe organisational actions will benefit them and generally have confidence in the words and actions of other people (Osa 2014).

Organisations provide incentives and facilities to employees for them to attain the maximum satisfaction level so that they perform their tasks, duties and responsibilities with the greatest possible intention and interest (Nawab, Khalid Bhatti \& Shafi 2011). The difference between an incentive and a reward is that an incentive aims to motivate further work and encourage a certain behaviour, whereas a reward acknowledges accomplished behaviour and has the potential to reinforce it (Yavuz 2004). It is in the best interest of a firm to have a system of incentives that applies to managers, other employees and the entire company (Gajic \& Medved 2010).

Incentive systems reside in an organisation's structure, rules, human resource management, opportunities, internal benefits, rewards, sanctions and so on. Based on both perception and research, organisational incentive systems have a significant influence on the performance of individuals and thus the organisation overall (UN Development Program 2006). Incentive systems for employees are critical for capacity development as they enable individuals and organisations to perform their functions effectively, efficiently and sustainably (UN Development Programme 2006). Because incentive systems are crucial for employees' performance, the process and dimensions of work incentives must be explained further.

\section{The process and dimensions of work incentives}

It is extremely important for the management of a company to successfully profile stimulation of employees (Jovanović, Živković \& Cvetkovski 2003). Three dimensions of stimulation influence an employee's performance: direction, intensity and persistence (Jovanović et al. 2003). If the intensity of stimulation is increased, then the employees will invest more effort in performing their tasks (Jovanović et al. 2003). This author points out that someone may be stimulated at an extremely high level, but only briefly, while someone else may be encouraged at a low level of intensity, but over a longer period. Subsequently, there is a need for adequate knowledge on types of incentive systems for employees.

\section{Types of incentive systems for employees}

Managers are constantly searching for ways to develop a motivational environment as they enable individuals and organisations to perform their functions effectively, efficiently and sustainably (Ballentine et al. 2003). Incentives may be divided into two types: monetary incentives and nonmonetary incentives (Yavuz 2004). Managers should develop incentive plans using a combination of monetary and nonmonetary incentives that reduce costs and provide short- and long-term benefits (Martin 2010). One way of stimulating people is to employ effective motivation, which makes workers more satisfied with and committed to their jobs. Money is not the only motivator. There are other 
incentives that can also serve as motivators (Osa 2014). Accordingly, the exploitation of financial or monetary incentives and non-financial or non-monetary incentives is undoubtedly one of the main foundations for understanding incentive systems.

\section{Financial or monetary incentives}

Both large and small businesses attempt to use financial incentives to motivate employees to achieve the organisation's objectives (Howard 2008). Some financial incentives are direct, such as salary, benefits, insurance and bonuses, and some are indirect, such as subsidising meals, clothing or housing (Singla 2009). Well-known financial incentives are pay and allowances, productivity-linked wage incentives, bonuses, profit sharing, co-partnership and retirement benefits. Many employees believe that money controls their environment and these employees respond well to monetary incentives (Jain 2005).

\section{Non-financial or non-monetary incentives}

Psychological rewards and rewards linked to status are some of the common forms of non-financial incentives. Besides power, self-esteem, self-actualisation, authority and status, employees also experience job satisfaction. According to Yavuz (2004), non-monetary incentives are tangible rewards, social practices or job-related factors. All three categories of non-monetary incentives have the potential to meet the various needs of employees without involving significant costs to the organisation, such as working from home, free time, free parking, gym memberships, mentoring and study or childcare assistance (Yavuz 2004). Because the concept of total rewards and a total rewards strategy and its elements include financial and non-financial incentives, knowledge of these aspects could advance an organisation's incentive systems.

\section{Total rewards and total rewards strategies}

Total rewards include financial and non-financial rewards provided to employees in exchange for their time, talents, effort and results (Worldatwork 2007). Armstrong and Brown (2006:266) show that the benefits of the total rewards approach are greater impact, enhancing the employment relationship, enhancing cost-effectiveness, flexibility to meet individual needs and winning the war for talent.

Rewards in the work environment are considered relational rewards and are associated with the emotional aspects of an employment relationship. Employers often customise these types of rewards to the specific needs of employees in order to differentiate themselves from their competitors, thus enhancing both attraction and retention (Kaplan 2005). When properly designed, delivered and communicated, a company's total rewards program can provide an incentive for talented people to join a company, to perform at levels that produce desired business results and to remain with the company as long as they continue to produce (Kwon, Hewitt \& Hein 2013).

\section{A total rewards strategy}

A total rewards strategy is a focused game plan that allocates resources and tailors activities to achieve a target performance level within a prescribed timetable (Hiles 2009). It must be unique to the organisation that develops it and when done effectively will help drive sustainable, competitive advantage (Hiles 2009). To be effective, a strategy must be holistic, integrated, aligned, measurable and delivered (Gross \& Friedman 2004). The elements of a total rewards strategy are compensation, benefits, work-life balance, performance and recognition, and development and career opportunities. These elements represent the 'tool kit' from which an organisation chooses to offer and align a value proposition that creates value for both the organisation and the employee (Kaplan 2005; Worldatwork 2007). Organisational learning is an important factor in achieving a sustainable competitive advantage (Galić 2010; Holjavec 2004; Paajanen et al. 2004) and motivating employees. A lack of organisational learning and the appropriate climate that supports learning have been visible in firms and this issue will be analysed in the next section.

\section{Organisational learning}

According to Senge (2001), a learning organisation is an organisation that continuously adapts to changes in its environment. A traditional organisation can be transformed into a learning organisation through self-mastery, mental models, creating a shared vision, team learning and systems thinking. In learning organisations, employees take risks, avoid hasty actions, show commitment and prefer teamwork and the synergetic effects of continuous group learning. Organisational learning is focused on five core disciplines, namely systems thinking, teamwork, a shared vision, mental models and personal skills (Senge 2001). Organisations are required to implant the aforementioned disciplines simultaneously (Rupčić 2007).

\section{The climate and factors of learning organisations}

If employees' perceptions of organisational climate influence their behaviours, it seems natural to assume that the organisational climate can be an important antecedent to their acceptance of technology. If employees realise that organisations put forth a substantial amount of effort to implement a technology, a climate is created that influences employees' behaviours by altering their attitudes and perceptions within the organisation (Yoo, Huang \& Lee 2012). To be able to learn, a climate that supports learning must govern in an organisation. According to Žugalj and Schatten (2005), crucial factors that affecta learning organisation climate are an awareness of the purpose of a learning organisation climate and its objectives; a clearly defined objective for each task; advising individuals; interpersonal relationships: people full of confidence, support, understanding; respect for individuality; access to information; exploiting opportunities for learning and providing resources; encouraging creative thinking; and understanding how the organisation works. 
Motivated employees are considered a vital link for the efficiency and effectiveness of a company and this is achieved through learning, education and training.

\section{Learning, education and training as foundations of organisational learning}

Highly motivated and skilled employees are becoming the primary source of a company's competitive advantage (Pološki-Vokić, Klindžić \& Đaković 2008). Today the most important principles of achieving high business performance are coaching, training and education of all employees in continuity (Živanović \& Živanović 2010). Training is becoming an increasingly important component in organisations because of the trend towards the introduction of new technologies resulting from the sharply competitive market and because of a lack of quality staff who are willing to take jobs for beginners (Živanović \& Živanović 2010).

This conceptual and theoretical framework provides descriptions of incentive systems, their dimensions and types. The focus of the discussion moves to perspectives on non-financial and monetary incentives that are explicitly visible through arguments on total rewards, total rewards strategies and an organisational learning climate. To equip employees with knowledge and skills, attitudes and values to improve their work performance and satisfaction, they need a model of an incentive system. A conceptual model of an incentive system is derived from multiple concepts clarified above and will be presented and justified in the next section.

\section{Model of incentive system for employees}

Based on the discussions above, a conceptual model of an employee incentive system was created. The foundation of this model is Maslow's theory of the hierarchy of needs (1943) that proposes that need is basic to behaviour (see Figure 1).

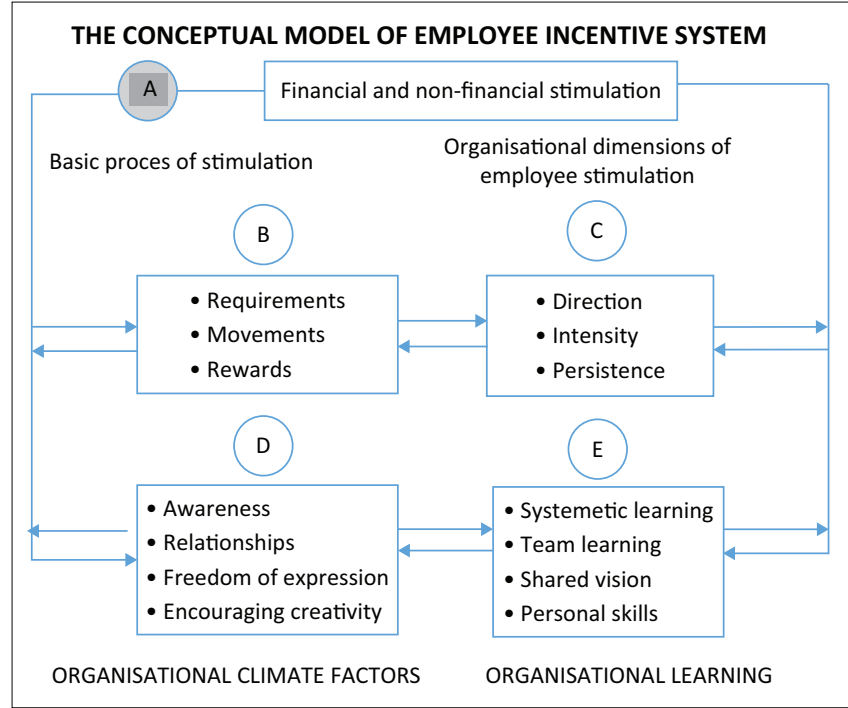

FIGURE 1: The conceptual model of an incentive system for employees.
The components of the conceptual model in Figure 1 are explained in Box 1 .

BOX 1: The components of the conceptual model.

(A) Financial and non-financial stimulation incentives.
(B) Requirements, movement, reward.
(C) Direction, intensity, persistence.
(D) Awareness, freedom to express opinions, relationships, encouraging creative
thinking.
(E) Systematic learning, team learning, shared vision, mental models and

The conceptual model of an incentive system for employees (Figure 1) shows the relationships between these related entities: A affects B, C, D and E; B affects A, C, D and E; C affects A, B, D and E; D affects A, B, C and E; E affects A, B, C and D.

\section{Research methodology Research approach}

In this empirical study a quantitative research methodology was applied (Biljan-August, Pivac \& Štambuk 2007; Zelenika 2000). According to Tkalac-Verčić, Sinčić Ćorić and Pološki Vokić (2010), the basis of the quantitative approach is the reliance on a theory or hypothesis, or questioning the set theory or hypotheses. This research uses a case study of a manufacturing company in Croatia. The case study looks into all factors and relationships between chosen variables, and it is a methodology that studies one instance or case in depth (Oates 2006; Yin 2009). Additionally, the researcher used the method of analysis and synthesis, compilation methods and statistical methods.

\section{The population and sample}

The population in this study consisted of 145 employees in a manufacturing company in Croatia. A sample of 42 managers was randomly drawn from the population (Dawson 2002). The sample included respondents at the middle and lower management levels. Of the total number of surveyed employees, $11(26.19 \%)$ of the respondents belonged to the middle management level, while 31 employees (73.8\%) belonged to a lower-level of management. Sampling error (Laczo et al. 2005) is a deviation of the selected sample from the true characteristics of the whole population and it emanates from the researcher drawing different subjects from the same population. To minimise sampling error, random sampling was applied (Suri 2011).

\section{Data-gathering methods and procedures for data collection}

Data was collected using a closed-ended type of questionnaire (Belak 2005; Goodyear 1998; Maree 2010). According to Tkalac-Verčić et al. (2010), a questionnaire is an instrument for collecting facts, opinions or attitudes in writing. The survey consisted of two parts and each part contained three questions. A seven-point Likert scale was used for the evaluation. The first part referred to the personal attitude of employees to the importance of incentive systems and 
organisational climate factors, while the second part referred to the actual condition of incentive systems and organisational climate factors. The questionnaire was distributed to participants via e-mail. Subsequently, the researcher had to follow up on these until the expected responses were received.

\section{Analysis of data}

Based on the defined hypotheses, dependent and independent variables were isolated. The dependent variables of this study were the importance of financial incentives, the importance of non-financial incentives, the presence of financial incentives, the presence of non-financial incentives, the importance of organisational climate factors and the presence of organisational climate factors. The independent variables of this study were the middle and lower levels of management.

The data was analysed using descriptive and inferential statistics. Descriptive statistics were used in the tabular display of data obtained through surveys and the presentation of research results by arithmetic means. The average of the importance and presence of financial and non-financial incentives and the average of the importance and presence of organisational climate factors were shown using arithmetic means. Using inferential statistics, hypotheses were tested and their acceptability was analysed. A software package for statistical data, SPSS 17.0, was used. The parametric $t$-test for paired samples was used, because the two groups under comparison are dependent on each other (middle and lower management). The parametric statistics test assumes that data follows one type of probability distribution, and inferences about the parameters of the distribution are derived from this analysis (Maruseri \& Bacarea 2010). The results of the data represented were interpreted to give account of this research and were presented in tabular form (Maree 2010).

\section{Assessment of trustworthiness}

According to Tkalac-Verčić et al. (2010), 'objectivity' implies honesty, morality and the ethics of research. The inclusion of the respondents was in accordance with ethical standards. 'Ethics' refers to the application of ethical principles and the appropriateness of behaviour in the preparation and implementation of the research, analysis and interpretation of the results (Tkalac-verčić et al. 2010). Participants signed the consent form. Data collected were used only for the purpose of this study and were kept confidential (Leedy \& Ormrod 2010). The researchers of this study followed the guidelines of Golafshani (2003) and Tkalac-Verčić et al. (2010).

'Validity' indicates the degree to which an instrument measures what it is supposed to measure. (Golafshani 2003; Leedy \& Ormrod 2010). Content validity and construct validity were checked through peer review by nonparticipants who provided feedback about the consistency and the relevance of questions in the questionnaire (Maree 2010) and refined the questions, format and scales (Creswell 2009). 'Reliability' in quantitative research refers to the repeatability of the results and indicates the consistency of the measurement of a concept (Cohen, Manion \& Morrison 2007; Tavakol \& Dennick 2011). Consistency in the questions was measured using Cronbach's alpha test (Reinard 2006; Tavakol \& Dennick 2011). The findings of this study are presented in the next section.

\section{Results of the research}

The aim of this section is to test the hypothesis using the manufacturing company. Table 1 presents the difference between the importance of financial and non-financial incentives to employees in middle and lower management levels using the $t$-test for paired samples.

It can be seen from Table 1 that the $p$-value for middle-level management is 0.44 , indicating that this difference is not statistically significant. Because the $p$-value is greater than 0.05 , the null hypothesis cannot be rejected. The table also shows that the level of significance ( $p$-value) for lower-level management is 0.85 . Because the $p$-value of 0.85 is greater than 0.05 the results are not statistically significant and Hypothesis 1 cannot be rejected.

Table 2 presents the difference between the level of presence of financial incentives and the importance of financial incentives for middle- and lower-level management using a $t$-test for paired samples.

Table 2 shows the results for Hypothesis 2. The middle-level management's $t$-test is 5.042 and the $p$-value is 0.000 . This leads to the conclusion that the results are statistically significant, that is, the null hypothesis is rejected because the $p$-value is less than 0.05 . The lower-level management's $t$-test

TABLE 1: Testing the difference between the importance of financial and nonfinancial incentives.

\begin{tabular}{lllccccc}
\hline $\begin{array}{l}\text { Level of } \\
\text { management }\end{array}$ & $\begin{array}{l}\text { Financial and non- } \\
\text { financial incentives }\end{array}$ & $\mathbf{N}$ & $\mathbf{M}$ & $\mathbf{s d}$ & $\mathbf{d f}$ & $\mathbf{t}$ & $\boldsymbol{p}$ \\
\hline Middle & Financial incentives & 11 & 3.943182 & 0.308036 & 10 & 0.796 & 0.44 \\
& $\begin{array}{l}\text { Non-financial } \\
\text { incentives }\end{array}$ & 11 & 3.845455 & 0.314209 & & & \\
Lower & Financial incentives & 31 & 3.616935 & 0.518346 & 30 & -0.192 & 0.85 \\
& $\begin{array}{l}\text { Non-financial } \\
\text { incentives }\end{array}$ & 31 & 3.645161 & 0.556081 & & & \\
\hline
\end{tabular}

sd, standard deviation; $\mathrm{M}$, the mean; $\mathrm{N}$, the total number of subjects sampled; $\mathrm{df}$, degree of freedom; $\mathrm{t}$ t $\mathrm{t}$-test; $p$, level of significance.

TABLE 2: Testing the difference between the presence and the importance of financial incentives.

\begin{tabular}{llcccccc}
\hline $\begin{array}{l}\text { Level of } \\
\text { management }\end{array}$ & Financial incentives & $\mathbf{N}$ & $\mathbf{M}$ & $\mathbf{s d}$ & $\mathbf{d f}$ & $\mathbf{t}$ & $\boldsymbol{p}$ \\
\hline Middle & $\begin{array}{l}\text { Importance of } \\
\text { financial incentives }\end{array}$ & 11 & 3.943182 & 0.308036 & 10 & 5.042 & $0.000^{*}$ \\
& $\begin{array}{l}\text { Presence of financial } \\
\text { incentives }\end{array}$ & 11 & 3.068182 & 0.408364 & & & \\
\hline & $\begin{array}{l}\text { Importance of } \\
\text { fowancial incentives }\end{array}$ & 31 & 3.616935 & 0.518346 & 10 & 4.703 & $0.000^{*}$ \\
& $\begin{array}{l}\text { Presence of financial } \\
\text { incentives }\end{array}$ & 31 & 2.895161 & 0.559107 & & & \\
\hline
\end{tabular}

sd, standard deviation; $M$, the mean; $N$, the total number of subjects sampled; df, degree of freedom; t, (t-test). 
is 4.703 and the $p$-value is 0.000 . Because the $p$-value is less than 0.05 , the results are statistically significant and Hypothesis 2 is rejected.

Table 3 shows the difference between the level of presence of non-financial incentives and the importance of non-financial incentives for middle- and lower-level management using a $t$-test for paired samples.

Table 3 shows the results for Hypothesis 3: the middle-level management's $t$-test is 5.670 and the $p$-value is 0.000 . Because the $p$-value is less than 0.05 , the results are statistically significant and the null hypothesis is rejected. The lowerlevel management's $t$-test is 8.791 and the $p$-value is 0.000 . Because the $p$-value is less than 0.05 , the results are statistically significant and Hypothesis 3 is rejected.

Table 4 shows the difference between the importance of organisational climate factors and the presence of organisational climate factors for middle- and lower-level management using a $t$-test for paired samples.

Table 4 shows Hypothesis 4 for middle-level management; the $p$-value is 0.008 . As the $p$-value is less than 0.05 , the results are statistically significant and the null hypothesis is rejected. For lower-level management the $p$-value is 0.000 . Because the $p$-value is less than 0.05 , the results are statistically significant and Hypothesis 4 is rejected.

Table 5 shows the importance of financial incentives, as indicated by employees on a scale from 1 (unimportant) to 7 (very important). The ranking of the importance of financial incentives shows that the average personal attitude of

TABLE 3: Testing the difference between the level of presence and the importance of non-financial incentives.

\begin{tabular}{llcccccc}
\hline $\begin{array}{l}\text { Level of } \\
\text { management }\end{array}$ & $\begin{array}{l}\text { Non-financial } \\
\text { incentives }\end{array}$ & $\mathbf{N}$ & $\mathbf{M}$ & $\mathbf{s d}$ & $\mathbf{d f}$ & $\mathbf{t}$ & $\boldsymbol{p}$ \\
\hline Middle & $\begin{array}{l}\text { Importance of non- } \\
\text { financial incentives }\end{array}$ & 11 & 3.845455 & 0.314209 & 10 & 5.67 & 0.000 \\
& $\begin{array}{l}\text { Presence of non- } \\
\text { financial incentives }\end{array}$ & 11 & 3.209091 & 0.396118 & - & - & - \\
Lower & $\begin{array}{l}\text { Importance of non- } \\
\text { financial incentives } \\
\text { Presence of non- } \\
\text { financial incentives }\end{array}$ & 31 & -3.645161 & 0.556081 & 30 & 8.791 & 0.000 \\
& - & - & - & - & - \\
\hline
\end{tabular}

$\mathrm{sd}$, standard deviation; $\mathrm{M}$, the mean; $\mathrm{N}$, the total number of subjects sampled; $\mathrm{df}$, degree of freedom; $\mathrm{t}$, $\mathrm{t}$-test, $p$; level of significance.

TABLE 4: Testing the difference between the level of importance and presence of organisational climate factors.

\begin{tabular}{llcccccc}
\hline $\begin{array}{l}\text { Level of } \\
\text { management }\end{array}$ & $\begin{array}{l}\text { Organisational } \\
\text { climate }\end{array}$ & $\mathbf{N}$ & $\mathbf{M}$ & $\mathbf{s d}$ & $\mathbf{d f}$ & $\mathbf{t}$ & $\boldsymbol{p}$ \\
\hline Middle & $\begin{array}{l}\text { Importance of } \\
\text { organisational } \\
\text { climate factors }\end{array}$ & 11 & 3.886364 & 0.50418 & 10 & 3.299 & 0.008 \\
\hline $\begin{array}{l}\text { Presence of } \\
\text { organisational } \\
\text { climate factors }\end{array}$ & 11 & 3.318182 & 0.392761 & & & \\
\hline & $\begin{array}{l}\text { Importance of } \\
\text { organisational } \\
\text { climate factors }\end{array}$ & 31 & 3.556452 & 0.551361 & 30 & 7.512 & 0.000 \\
\hline $\begin{array}{l}\text { Presence of } \\
\text { organisational } \\
\text { climate factors }\end{array}$ & 31 & 2.850806 & 0.643412 & & & & \\
\hline
\end{tabular}

sd, standard deviation; $\mathrm{M}$, the mean; $\mathrm{N}$, the total number of subjects sampled; df, degree of freedom; $\mathrm{t}$ t -test, $p$; level of significance. employees to the importance of financial incentives ranged from 4.33 for allowance for overtime to 2.57 for profit sharing.

Table 6 shows the presence of financial incentives in the research enterprise. Employees had to rate the presence of each of the financial incentives from 1 (under-represented) to 7 (well represented). The results show that the average presence of financial incentives ranged from 3.809 for travel expenses to 1.88 for profit sharing and shares in the company.

Table 7 shows the value the staff attaches to non-financial incentives. These incentives were rated on a scale from 1 (unimportant) to 8 (very important). The averages ranged from 4.64 for job security to 3.095 for flexible working hours.

Table 8 shows the presence of non-financial incentives. The employees ranked these from 1 (under-represented) to 10 (well represented). The averages ranged from 3.76 for quality of interpersonal relationships in the firm to 2.11 for various

Table 5: Employees' attitude towards financial incentives.

\begin{tabular}{llccc}
\hline Particle & $\begin{array}{l}\text { Employees' personal attitude towards } \\
\text { financial incentives }\end{array}$ & Average & STDEV & $\begin{array}{c}\text { Rank of } \\
\text { importance }\end{array}$ \\
\hline F1 & $\begin{array}{l}\text { Wage increase proportional with } \\
\text { productivity increase }\end{array}$ & 3.904762 & 0.983015 & 5 \\
F2 & Profit sharing & 2.571429 & 0.940754 & 1 \\
F3 & Bonuses & 4.285714 & 0.891305 & 7 \\
F4 & Award for year of work service & 3.738095 & 1.210916 & 3 \\
F5 & Travel expenses & 4.166667 & 0.793777 & 6 \\
F6 & Compensation for use of annual leave & 3.880952 & 0.705462 & 4 \\
F7 & Allowance for overtime & 4.333333 & 0.90167 & 8 \\
F8 & Participation in profit & 2.738095 & 1.083345 & 2 \\
\hline
\end{tabular}

STDEV, standard deviation.

Table 6: Presence of financial incentives in the research enterprise. Particle Employees' personal attitude towards Average STDEV Rank of

\begin{tabular}{lllcc}
\hline Particle & $\begin{array}{l}\text { Employees' personal attitude towards } \\
\text { financial incentives }\end{array}$ & Average & STDEV & $\begin{array}{c}\text { Rank of } \\
\text { importance }\end{array}$ \\
\hline PF1 & $\begin{array}{l}\text { Wage increase proportional with } \\
\text { productivity increase }\end{array}$ & 2.666667 & 1.05152 & 2 \\
PF2 & Profit sharing & 1.880952 & 0.88902 & 1 \\
\hline PF3 & Bonuses & 3.357143 & 0.98331 & 5 \\
PF4 & Award for year of work service & 3.309524 & 1.11504 & 4 \\
PF5 & Travel expenses & 3.809542 & 0.6713 & 7 \\
PF6 & Compensation for use of annual leave & 3.238095 & 0.759 & 3 \\
PF7 & Allowance for overtime & 3.380952 & 0.90937 & 6 \\
\hline PF8 & Participation in profit & 1.880952 & 0.86115 & 1 \\
\hline
\end{tabular}

STDEV, standard deviation.

Table 7: Personal attitudes of the staff to the importance of non-financial incentives.

\begin{tabular}{|c|c|c|c|c|}
\hline Particle & $\begin{array}{l}\text { Employees' personal attitude towards } \\
\text { financial incentives }\end{array}$ & Average & STDEV & $\begin{array}{c}\text { Rank of } \\
\text { importance }\end{array}$ \\
\hline Nf1 & Organisational climate & 3.809524 & 0.890001 & 5 \\
\hline $\mathrm{Nf} 2$ & Opportunity for advancement & 4.309524 & 0.780497 & 6 \\
\hline $\mathrm{Nf3}$ & Job enrichment & 3.285714 & 1.110608 & 2 \\
\hline $\mathrm{Nf4}$ & Recognition & 3.785714 & 1.000871 & 4 \\
\hline Nf5 & Job security & 4.642857 & 0.655983 & 8 \\
\hline Nf6 & $\begin{array}{l}\text { Quality of interpersonal relationship in } \\
\text { the company }\end{array}$ & 4.47619 & 0.772645 & 7 \\
\hline Nf7 & Flexible working hours & 3.095238 & 0.22593 & 1 \\
\hline Nf8 & $\begin{array}{l}\text { Opportunity of further educational and } \\
\text { personal development }\end{array}$ & 3.190476 & 1.194256 & 3 \\
\hline
\end{tabular}

STDEV, standard deviation. 
TABLE 8: Presence of non-financial incentives in the company.

\begin{tabular}{|c|c|c|c|c|}
\hline Particle & $\begin{array}{l}\text { Employees' personal attitude to } \\
\text { financial incentives }\end{array}$ & Average & STDEV & $\begin{array}{c}\text { Rank of } \\
\text { importance }\end{array}$ \\
\hline PNf1 & Organisational climate & 3.547619 & 0.66997 & 8 \\
\hline PNf2 & Opportunity for advancement & 3.1190448 & 0.669997 & 7 \\
\hline PNf3 & Job enrichment & 3.047619 & 0.824987 & 6 \\
\hline PNf4 & Recognition & 2.595238 & 0.766987 & 4 \\
\hline PNf5 & Job security & 3.738095 & 0.627015 & 9 \\
\hline PNf6 & $\begin{array}{l}\text { Quality of interpersonal relationship in } \\
\text { the company }\end{array}$ & 3.761905 & 0.758996 & 10 \\
\hline PNf7 & Flexible working hours & 2.619048 & 0.986553 & 5 \\
\hline PNf8 & $\begin{array}{l}\text { Opportunity of further educational and } \\
\text { personal development }\end{array}$ & 2.5 & 0.96033 & 3 \\
\hline PNf9 & $\begin{array}{l}\text { Support of superiors in the personal } \\
\text { guidance }\end{array}$ & 2.452381 & 0.942296 & 2 \\
\hline PNf10 & Various benefits & 2.119048 & 1.986556 & 1 \\
\hline
\end{tabular}

STDEV, standard deviation.

TABLE 9: Importance of organisational climate factors to employees.

\begin{tabular}{|c|c|c|c|c|}
\hline Particle & $\begin{array}{l}\text { Employees' personal attitude towards } \\
\text { organisational factors }\end{array}$ & Average & STDEV & $\begin{array}{c}\text { Rank of } \\
\text { importance }\end{array}$ \\
\hline FO1 & $\begin{array}{l}\text { Realistic and clear setting of goals and } \\
\text { tasks }\end{array}$ & 3.714286 & 0.969931 & 4 \\
\hline FO2 & Appropriate degree of independence & 3.785714 & 1.02495 & 5 \\
\hline FO3 & Good work is highly valued & 3.928571 & 0.777515 & 6 \\
\hline FO4 & $\begin{array}{l}\text { Quickly noticing and rewarding good } \\
\text { performance }\end{array}$ & 3.918571 & 0.837908 & 6 \\
\hline FO5 & Everybody knows its duties & 3.714286 & 0.708338 & 5 \\
\hline FO6 & Information access & 3.309524 & 0.923622 & 2 \\
\hline FO7 & $\begin{array}{l}\text { Full harmonisation of the powers and } \\
\text { responsibilities at all levels }\end{array}$ & 3.619048 & 1.034818 & 3 \\
\hline FO8 & Encouraging creativity and innovation & 3.142857 & 1.260496 & 1 \\
\hline
\end{tabular}

STDEV, standard deviation.

TABLE 10: Presence of organisational climate factors in the company.

\begin{tabular}{|c|c|c|c|c|}
\hline Particle & $\begin{array}{l}\text { Employees' personal attitude towards } \\
\text { organisational factors }\end{array}$ & Average & STDEV & $\begin{array}{c}\text { Rank of } \\
\text { importance }\end{array}$ \\
\hline FO1 & $\begin{array}{l}\text { Realistic and clear setting of goals and } \\
\text { tasks }\end{array}$ & 3.071429 & 0.866528 & 5 \\
\hline FO2 & Appropriate degree of independence & 3.52381 & 1.06469 & 8 \\
\hline FO3 & Good work is highly valued & 3.02381 & 0.780497 & 4 \\
\hline FO4 & $\begin{array}{l}\text { Quickly noticing and rewarding good } \\
\text { performance }\end{array}$ & 2.642857 & 0.759378 & 2 \\
\hline FO5 & Everybody knows its duties & 3.428571 & 0.966332 & 7 \\
\hline FO6 & Information access & 2.738095 & 0.885094 & 3 \\
\hline FO7 & $\begin{array}{l}\text { Full harmonisation of the powers and } \\
\text { responsibilities at all levels }\end{array}$ & 3.095238 & 1.185471 & 6 \\
\hline FO8 & Encouraging creativity and innovation & 2.261905 & 0.857094 & 1 \\
\hline
\end{tabular}

STDEV, standard deviation.

benefits, such as free tickets to various locations, gift vouchers and free parking.

Table 9 shows the value employees attach to organisational climate factors, ranked on a scale from 1 (unimportant) to 6 (very important). The averages ranged from 3.928 for quickly noticing and rewarding good performance to 3.14 for encouraging creativity and innovation.

Table 10 shows the presence of factors in the organisational climate of the company, ranked on a scale from 1 (underrepresented) to 8 (well represented). The averages ranged from 3.52 for an appropriate degree of independence to 2.26 for encouraging creativity and innovation. Based on these results and the conceptual model, the MIS is created and presented next.

\section{Summary of findings}

Hypothesis testing was carried out on middle and lower management levels. Based on the results of the $t$-test, Hypothesis 1 was accepted; the null hypothesis was that the non-financial incentives were not more important than financial incentives for the middle and lower management levels. There was very little difference between the importance of these financial and non-financial incentives among tested employees.

In Hypothesis 2 the null hypothesis was rejected and the alternative hypothesis, namely that there was a difference between the level of presence and the importance of financial incentives for the middle and lower levels of management, was accepted.

In Hypothesis 3 the null hypothesis was rejected and the alternative, which states that there is a difference between the level of presence and the importance of non-financial incentives for the middle and lower management levels, was accepted.

In Hypothesis 4 the null hypothesis was rejected and the alternative hypothesis was accepted, namely that there was a divergence between important factors in the organisational climate and its presence for the management levels.

Figure 2 shows the model of an incentive system.

The components of the conceptual model (A, B, C, D, E) have been implicitly incorporated into the MIS model (see Figure 1). The MIS model is based on the findings of this study, which highlight the importance of the organisational climate to attract employees and provide opportunities for the development of their professional, personal and creative capabilities. The model implicitly reflects the importance of non-financial incentives (e.g. job security, flexible working hours, overtime allowance, encouraging creativity and innovation) and financial incentives (e.g. profit sharing, travel expenses) as well as a stimulating organisational climate that improves the satisfaction and productivity of the employees.

From this model it can be seen that the results of the research are related to one another or to the organisation's

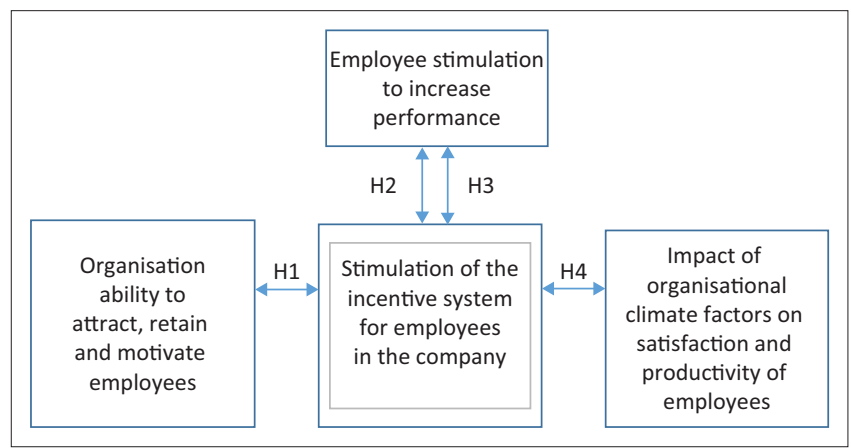

FIGURE 2: The model of an incentive system. 
ability to attract, retain and motivate employees (Hypothesis 1). It is evident that stimulating employees to increase their performance (Hypotheses 2 and 3), in addition to the impact of organisational climate factors on the satisfaction and productivity of workers (Hypothesis 4 ), can affect the incentive system for employees and vice versa. The next section provides an analysis and discussion of the results.

\section{Discussion}

The theoretical framework for incentive systems comprises a variety of issues that were discussed earlier on in this article and the MIS model was derived (see Figure 2). The quality of the work environment is important to organisations and it is necessary to generate a model that can be used for a successful incentive practice. Organisations use incentives, which are divided into financial or monetary and non-financial or nonmonetary incentives, to motivate employees to increase their performance.

Employees claimed that the financial incentives that were best represented are payments for overtime, bonuses and travel expenses. Employees claimed that the non-financial incentives that were best represented are quality interpersonal relationships, job security, the opportunity for advancement and encouragement of creativity and innovation (as an answer to RQ1: Which incentives are used to stimulate employees to increase their performance?). These findings have been supported by other researchers (e.g. Jain 2005; Osa 2014; Singla 2009; Yavuz 2004).

Employees are considered the most valuable asset of the company, so the main task is monitoring employees' motivation and rewarding them accordingly. The benefits of total rewards and total rewards strategies are crucial to empowering work environments (Hiles 2009; Kaplan 2005; Kwon et al. 2013). If management in organisations consistently signal that they treat employees fairly by giving them appropriate non-financial support and offering them suitable financial incentives, it is likely that it will lead to better performance.

According to employees, the financial incentive that was most important is payment for overtime and the most important non-financial incentive was job security. Specifically, the most common financial incentive in the studied company was travel expenses and the most common non-financial incentive was good interpersonal relationships. The company under investigation should contribute to building good interpersonal relationships and ensure job security in addition to providing payments for overtime and travel expenses (as an answer to RQ2: How do employee benefits affect the organisation's ability to attract, retain and motivate employees?).

Exploring the factors of an organisational climate is a prerequisite for the development of an organisation and the increased level of satisfaction and productivity of its employees (Galić 2010; Holjavec 2004; Paajanen et al. 2004). Identifying the appropriate factors of organisational climate can lead to the creation of an organisational environment that is conducive to greater success and the advancement of human resources (Senge 2001; Yoo et al. 2012; Žugalj \& Schatten 2005).

The subjects of our research offered organisational climate factors, of which the most important were quickly noticing and rewarding good business results and appreciating a job well done. The respondents also stated that an appropriate degree of independence was the most prevalent factor in the organisational climate and secondly knowing the specific duties of each employee (as an answer to RQ3: How do organisational climate factors influence satisfaction and employee productivity?).

The research on incentive systems for employees (e.g. Hales et al. 2009; Kamery 2004; Nawab et al. 2011) in a synergy with the three dimensions of stimulation (Jovanović et al. 2003) and the MIS model can enable employees to perform efficiently and sustainably (UN 2006). The integration of organisational learning that adapts to new technologies (Yoo et al. 2012) can positively influence employees' behaviour and attitudes.

\section{Conclusions, limitations and future research}

This study presents an innovative insight into an incentive system for middle- and lower-level management for a manufacturing company in Croatia. It also develops a conceptual model, refines it and creates an integrated MIS model. The discussions above strongly support the following general conclusions:

- Incentive systems used by the studied company in Croatia have proven to be very important to employees. The most significant financial incentives were considered payments for overtime, bonuses and travel expenses. The most important non-financial incentives were job security, the quality of interpersonal relationships and the opportunity for advancement.

- The actual presence of the incentive stimulations of employees was far below the expectations of employees, or what they considered to be essential in order to perform their jobs effectively. Organisations should try to meet certain expectations of employees regarding incentives because satisfied employees are in demand (Ahmed et al. 2011).

- The factors of a positive organisational climate were under-represented. The expectations of employees regarding certain factors of a positive organisational climate were higher than the actual situation in the company. The best represented factor was an appropriate degree of independence. The company should continuously monitor the organisational climate and employee satisfaction and introduce organisational changes aimed at improving the business. 
In summary, we contend that a model can provide a strategy to realise employees' creative performance through an appropriate incentive system. From here, a shift to rethinking and restructuring the organisational incentive systems is necessary in organisational settings.

Contributions or originality and value-add: The theoretical outline and findings of this study provide a solid basis for an employee incentive system. The review of the literature represents an attempt to organise the scientific knowledge on the multiple aspects of incentive systems leading to the derivation of a model for incentive systems that is essential to developing organisational commitment and trust. Several critical aspects of incentive systems are described that could empower production, creativity and innovation in organisations.

Limitations: Conclusions from this study should be tentatively applied because a small sample of employees from middle and lower management levels were examined within one manufacturing company as a single case study. Although a theoretical rationale suggests that the model should be widely applicable, too few examples are given in this article to provide conclusive evidence of wide applicability. The authors believe that some practice-based research is necessary to complement the theoretical and practical perspective on the devised MIS.

In order to do further research, the MIS should be examined with regard to other demographic criteria such as gender, age and length of service. The model can be further examined in terms of its strategy, structure and functionalities. It would be fruitful to repeat similar research on a larger sample in order to gain more accurate results.

\section{Acknowledgements Competing interests}

The authors declare that they have no financial or personal relationships which may have inappropriately influenced them in writing this article.

\section{Authors' contributions}

The first author M.J. led the study, analysed the data and edited the article. The second author J.Z. created the theoretical framework, gathered the data and edited the article. The third author A.C. edited the article.

\section{References}

Ahmed, I., Ahmad, Z., Musarrat Nawaz, M. \& Zafard, A., 2011, 'Explicit and implicit factors of job satisfaction: A combination that works', Interdisciplinary Journal of Contemporary Research in Business 2(12), viewed 15 September 2011, from http://www.allbusiness.com

Armstrong, M. \& Brown, D., 2006, Strategic reward: Making it happen, Kogan Page London, UK.

Ballentine, A., McKenzie, N., Wysocki, A., Kepner, K., Farnsworth, D. \& Clark, J.L., 2003, The role of monetary and non-monetary incentives in the workplace as influenced by career stage, IFAS Extension, University of Florida, pp. 1-3, viewed 15 September 2011, from https://edis.ifas.ufl.edu/pdffiles/HR/HR01600.pdf

Belak, S., 2005, Uvod u znanost, Visoka škola za turistički menadžment u Šibeniku, Šibenik, viewed 15 September 2011, from http://www.vus.hr
Biljan-August, M., Pivac, S. \& Štambuk, A., 2007, Uporaba statistike u ekonomiji, Ekonomski fakultet sveučilišta u Rijeci, Rijeka.

Creswell, J.W., 2009, Research design: Qualitative, quantitative, and mixed methods approaches, 3rd edn., Sage, Thousand Oaks, CA.

Cohen, L., Manion, L. \& Morrison, K., 2007, Research methods in education, Routledge, New York.

Dawson, C., 2002, Practical research methods, UBS Publisher's Distributors, New Delhi.

Dur, R., Non, A. \& Roelfsema, H., 2010, 'Reciprocity and incentive pay in the workplace', Journal of Economic Psychology 31(4), 676-686. https://doi.org/10.1016/ j.joep.2010.05.001

Gajic, L.J. \& Medved, I., 2010, 'Financial segment in the function of building a motivation and rewarding system', Business and Economic Horizons 2(2), 67-74. https://doi.org/10.15208/beh.2010.18

Galić, M., 2010, Učešće organizacije, Medianali 4(2), 179-194.

Golafshani, N., 2003, 'Understanding reliability and validity in qualitative research', The Qualitative Report 8(4), 597-607.

Goodyear, M., 1998, 'Qualitative research', in C. McDonald \& P. Vangelder (eds.), The Esomar handbook of market and opinion research, pp. 221-361, ESOMAR, Amsterdam.

Gross, S.E. \& Friedman, H.M., 2004, 'Creating an effective total reward: Holistic approach better supports business success', Benefits Quarterly 20(3), 7-13.

Hales, J. \& Williamson, M.G., 2009, 'Implicit employment contracts: The limits of management reputation for promoting firm productivity', Journal of Accounting Research 48(1), 147-176. https://doi.org/10.1111/j.1475-679X.2009.00352.x

Hiles, A., 2009, 'Tough times demand focus - Total rewards strategy', Benefits Quarterly 25(4), 44.

Holjavec, I., 2004, 'Europa znanja: Organizacija koja uči i sustav upravljanja kvalitetom', Zbornik radova 6 . međunarodnog simpozija menadžera kvalitete: Kvalitetom u Europske integracije, Zadar, Oskar, Zagreb, 18-20th October, pp. 149-156.

Howard, J.L., 2008, 'The use of non-monetary motivators in small business', The Entrepreneurial Executive 13, viewed 23 September 2011, from http://www. sciencedirect.com

Jain, N.K., 2005, Organizational behavior [e-book], Atlantic Publishers \& Distributors, New Delhi, viewed 23 September 2011, from http://books.google.hr

Jovanović, M., Živković, M. \& Cvetkovski, T., 2003, Organizaciono ponašanje, Megatrend univerzitet primjenjenih znanosti, Beograd, viewed 01 December 2011, from http://www.scribd.com

Kamery, R.H., 2004, 'Employee motivation as it relates to effectiveness, efficiency, productivity and performance', Proceedings of the Academy of Legal, Ethical and Regulatory Issues 8(2), 139-144.

Kaplan, S., 2005, 'Total reward in action: Developing a total rewards strategy', Benefits \& Compensation Digest 42(8), 32-37.

Kurtić, A., 2009, Osnove menadžmenta, Tuzla, Off-set, viewed 01 December 2011, from http://www.scribd.com

Kwon, J., Hewitt, A. \& Hein, P., 2013, Employee benefits in a total rewards framework, pp. 32-38, viewed 01 December 2011, from http://www.ifebp.org

Laczo, R.M., Sackett, P.R., Bobko, P. \& Cortina, J.M., 2005, 'A comment on sampling error in the standardized mean difference with unequal sample sizes: Avoiding potential errors in meta-analytic and primary research', Journal of Applied potential errors in meta-analytic and primary research', Journal of $A$
Psychology 90, 758-764. https://doi.org/10.1037/0021-9010.90.4.758

Leedy, P.D. \& Ormrod, J.E., 2010, Practical research: Planning and design, 9th edn., Merrill, Upper Saddle River, NJ.

Maree, K., 2010, First steps in action research, 5th edn., Van Schaik Publishers, Pretoria.

Martin, K., 2010, 'Cash motivation limited', Pennsylvania CPA Journal 81(1), 1.

Maruseri, M. \& Bacarea, V., 2010, 'Comparing groups for statistical differences: How to choose the right statistical test', Biochemia Medica 20(1), 15-32. https://doi. org/10.11613/BM.2010.004

Nawab, S., Khalid Bhatti, K. \& Shafi, K., 2011, 'Effect of motivation on employees' performance', Interdisciplinary Journal of Contemporary Research in Business 3(3), 1209-1216.

Oates, B.J., 2006, Researching information systems and computing, Sage, London.

Osa, I.G., 2014, 'Monetary incentives motivates employees on organizational performance', Global Journal of Arts, Humanities and Social Sciences 2(7), 61-69.

Paajanen, P., Kantola, J., Karwowski, W. \& Vanharanta, H., 2004, 'Applying systems thinking in the evaluation of organization learning and knowledge creation', Journal of Systematic, Cybernetic and Informatics 3(3), 79-84.

Pološki-Vokić, N., Klindžić, M. \& Đaković, M., 2008, 'Work motivation of highly educated Croatian employees - What should managers and HR experts know?' South East European Journal of Economics and Business 3(1), 89-96.

Reinard, J.C., 2006, Communication research statistics, Sage, Thousand Oaks, CA.

Rupčić, N., 2007, 'Kritički osvrt na koncept organizacije koja uči', Društvo Istraživanja 6(92), 1239-1261.

Schottner, A., 2010, 'Promotion tournaments and individual performance pay', Journal of Economics \& Management Strategy 19(3), 699-731. https://doi org/10.1111/j.1530-9134.2010.00267.x

Senge, P., 2001, The fifth discipline: Principles and practice of learning organizations, Mosaic books, Zagreb. 
Singla, R.K., 2009, Business management, [e-book], FK, New Delhi.

Suri, H., 2011, 'Purposeful sampling in qualitative research synthesis', Qualitative Research Journal 11(2), 63-75. https://doi.org/10.3316/QRJ1102063

Tavakol, M. \& Dennick, R., 2011, 'Making sense of Cronbach's alpha', International Journal of Medical Education 2, 53-55. https://doi.org/10.5116/ijme. $4 \mathrm{dfb} .8 \mathrm{dfd}$

Tkalac Verčić, A., Sinčić Ćorić, D. \& Pološki Vokić, N., 2010, Priručnik za metodologiju istraživačkog rada, MEP, Zagreb.

UN Development Programme, 2006, Incentive systems: Incentives, motivation and development performance, Conference Paper series Production team, Capacity Development Group/BDP, viewed 15 September 2011, from http:// www.lencd.co

Worldatwork, 2007, The WorldatWork handbook of compensation, benefits \& total reward: A comprehensive guide for HR professionals, John Wiley and Sons, Hoboken, NJ.
Yavuz, N., 2004, 'The use of non-monetary incentives as a motivation tool: A survey study in a public organization in Turkey', Master's thesis, Middle East Technical University, Political Science and Public Administration Dept., Ankara.

Yin, R.K., 2009, Case study research: Design and methods, 4th edn., Sage, Thousand Oaks, CA.

Yoo, S.J., Haung, W. \& Lee D., 2012, 'The impact of employees' perception of organizational climate on their technology acceptance toward e-learning in South Korea', Knowledge Management \& E-Learning: An International Journal 4(3), 359-377.

Zelenika, R., 2000, Metodologija i tehnologija izrade znanstvenog i stručnog djela, Ekonomski fakultet, Rijeka.

Živanović, N. \& Živanović, V., 2010, 'Trening i edukacija za stvaranje organizacijske klime pogodne za poslovne rezultate', International Scientific Conference, viewed 01 February 2012, from www.fimmanager.edu.rs

Žugalj, M. \& Schatten, M., 2005, Arhitektura suvremenih organizacija, Tonimir Fakultet organizacije i informatike, Varaždinske Toplice. 